\title{
DET GRÖNA PORSLINPALATSET
}

\section{Erik Hofrén}

H. G. Wells (1866-1946) var en märklig man, stor som journalist och forfattare, aktiv internationalist och illusionslös visionär.

Sean McBride, ansvarig for Unesco-rapporten 'Many Voices - One World', fann anledning parafrasera Wells: "Mänsklig historia börjar mer och mer bli en kapplöpning mellan kommunikation och katastrof. Full användning av kommunikation med alla dess skiftande inslag är betydelsefull för att tillforsäkra mänskligheten mer än en historia och våra barn en framtid." I denna formulering sammanfattas Wells' internationella patos.

Ar 1895 utkom den bok som mer än någon annan är förbunden med Wells: Tidmaskinen.

Som Teddy Brunius skriver i sin fina inledning till 1986 års svenska utgåva (den första utgavs 1916 under namnet Den underbara resan) dramatiserar H. G. Wells skickligt vetenskapens och teknikens möjligheter. Det är i sig inget nytt, Science Fiction, vetenskapsfabeln, är en gammal litterär form. Cyrano de Bergerac, exempelvis, skildrar en färd till månen, ett tema som återkommer från Tusen och en natt till Münchhausen.

Men, som 'Brunius också poängterar, $\mathrm{H}$. G. Wells hade upptäckt framtiden som ett litterärt tema. Han angav principerna för en futurologi. För att förstå sin egen tid måste man begripa historiens gång och frammana framtidsperspektiv. Wells inledde den traditionen i litteraturen. Och den är en av de viktigaste kraftlinjerna för en uppehållande strategi för människovärdet.
Om framtiden skall ha en framtid måste den ha ett förgånget skriver Carlos Fuentes i sin fängslande uppsats In $i$ 80talet:

Mer än någon annan disciplin talar dikten med kraft om för oss att om man kör ut det förgångna genom fönstret, så kommer det tillbaka genom ytterdörren och därtill utstyrd $i$ de underligaste maskiner och förklädnader. Krigen mot minnet förloras till slut av dem som är ansvariga för dem.

$1895 \times 3$

H. G. Wells upptäckte framtiden som ett litterärt tema med sin Tidmaskin, modellår 1895.

Det är en händelse som ser ut som en tanke att samma år, den 28 december, demonstrerar bröderna Auguste och Louis Lumière sin cinematographe på Grand Café, 14 Bd des Capucines i Paris. Med filmen skapades den moderna tidens kan- 
84 ske mest effektiva kommunikationsmedium (gärna instämmer jag i Colin Sorensons förundran över hur föga museerna brukar filmen som historiskt tidsdokument och som medium för samtidsdokumentation).

Alltså 1895 gånger tre. Den amerikanske ingenjören Frederick W. Taylor håller sina första föreläsningar för ingenjörer och blir en förgrundsgestalt för en teori, taylorismen, vars bärande idé är att skilja mellan arbetets planering och ledning och arbetets utförande. Som Bo Göranzon framhåller, kan man i effektivitetsrörelsen kring sekelskiftet 1900 urskilja en tendens att beskriva arbetet som djuriskt eller maskinliknande. Ibland överfördes den beskrivningen till arbetaren själv. Hos F.W. Taylor återfinns frispråkiga jämförelser mellan arbetaren och människans släktingar, hunden och oxen. En förstklassig arbetare skall lyda som en hund. Och om det krävs hårt arbete bör företagsledningen välja en arbetare som både fysiskt och psykiskt är av oxtypen.

I Charlie Chaplins konstnärskap och hans Moderna tider (1936) möts bröderna Lumière och F.W. Taylor. Det finns stora beröringsytor just mellan Wells och Chaplin (som det vore intressant att $\mathrm{i}$ annat sammanhang beröra). Den sammanbindande röda tråden går snabbt att urskilja - förhållandet till arbetets värde och arbetarens värdighet.

Det är alltför lätt att förbigå att det är detta som är det grundläggande temat i Tidmaskinen. Hans tidmaskin för inte till den gyllene tidsåldern. Framtidens människor har obönhörligen splittrats i exploatörer och exploaterade.

På sin vandring i skuggornas dal kommer romanens Tidfarare till «Det gröna porslinpalatset» (ruinerna efter ett sena tiders Kensington Museum):

Att döma av det gröna porslinpalatsets yttre måste där finnas mycket mer än den paleontologiska avdelningen. Troligen också historiska avdelningar, kanske rent av bibliotek!

Tidfararen når också ett sådant och utbrister:

Hade jag varit författare, skulle jag kanske ha moraliserat över det fåfänga $\mathrm{i}$ all mänsklig strävan. Vad som nu mest slog mig var det enorma slöseri med arbetskraft som denna dystra öken av multnande papper bar vittne om. Jag făr erkänna att jag därvid närmast tänkte på våra naturvetenskapliga tidskrifter och mina egna sjutton uppsatser om den fysiska optiken.

Det kan tilläggas att $\mathrm{H}$. G. Wells själv hade skrivit en lärobok i biologi. Det halvt fallfärdiga gröna porslinpalatset är ett slags allmuseum, resultatet av människans arbete och hennes förhållande till naturen. Som lär oss att det är, inte monumenten; utan ruinerna, som undervisar oss i historia.

Mer än fyrtio år efter "Tidmaskinens» utgivning drömmer H. G. Wells om en permanent världsencyklopedi i form av en sammansmältning av världens katalogiserade arkiv:

Det finns inte längre något praktiskt hinder för att åstadkomma en väl fungerande katalog över all mänsklig kunskap, alla idéer och prestationer, dvs att skapa ett komplett globalt mänsklighetens minne. Och inte bara en katalog; reproduktioner av själva objekten kan förmedlas till varje på lämpligt sätt utrustad plats.

H. G. Wells brukar bilden av «Det gröna 
porslinpalatset» som om det vore den låda med tidsdokument man murar in vid grundläggningen av nya palats, dvs här är det samhället som är huset och museet lådan.

Vad viktigare är. Det finns alltid ett samhälleligt sammanhang, museerna är med eller mot sin vilja - sociala tidsrum.

\section{MUSEET FRAN DÄRFÖR TILL VARFÖR}

Som ung museiman bar jag ständigt med mig påståendet: Därför museum! Nu med många yrkesår $\mathrm{i}$ ränseln är det istället en fråga som tynger: Varfor museum? Denna fråga kan naturligtvis utvecklas och bli till ett träd med många grenar. Men vad är det för behov som trädets krona skall ge svalka och liv? Vårt behov av tröst, av distans, av närhet, av gemenskap eller av avskildhet. Är det vårt behov av kontinuitet, identitet, legitimitet?

I sin intresseväckande bok från 1979, Museums in motion, citerar Edward P. Alexander en svart poet, June Jordan:

Take me into the museum and show me myself, show me my people, show me soul America. If you cannot show me myself, if you cannot teach my people what they need to know - and they need to know that nothing is more important than human life - if you cannot show and teach these things, then why shouldn't I attack the temples of America and blow them up? The people who hold the power, and the people who count pennies, and the people who hold the keys better start thinking it all over again.

Det sagda kan ge upphov till flera tankar. Det är uppenbart att museet ses som den institution som samhälleligt legitimerar ett kulturarv. Inte blott att se utan även att bli sedd, inte blott att lyssna utan även att bli lyssnad till.

\section{MUSEET UTÖVAR MAKT}

Det är således angeläget att se den dialog museet eftersträvar $\mathrm{i}$ ett maktperspektiv. Den norske sociologen Stein Braathen diskuterar i sin bok, Dialogens villkor i datasamfundet, huruvida kunskap ger makt och vem som i så fall får den.

Tillkommer makten den som tillägnar sig kunskap eller den som erbjuder kunskap på sina premisser? Kommer den ökade informationen som följer med elektroniskt baserade nätverk att bredda åsiktsspektrat - eller tvärtom bidra till åsiktsmonopol, där media som når de många samverkar med nätverk som sammanbinder de få?

Frågorna borde bränna till och tända eldar i museilandskapet.

Vi bär alla på en karta över oss själva. Vår karta över oss själva är en del av vårt eget landskap, vår självförståelse. Godtar vi en bestämd karta som allenarådande, kan vi komma att anpassa oss som landskap till denna karta. Våra självbilder, modeller av verkligheten formas av forskare, politiker, journalister, terapeuter, konstnärer, (museimän?)' och andra medlemmar av symboleliten med institutioner till sitt förfogande.

För att frigöra oss från beroende och underlägsenhet behövs alternativa verklighetsmodeller. Då vidgas synfältet. Vi måste vara på vakt för att avslöja sammanhang där endast en synvinkel är förhärskande, en verklighetsuppfattning allenarådande. Vi måste aktivt stimulera en dialog mellan självständiga synsätt. 
ERIK HOFREN

86 Makt kan också utövas på ett mer oförargligt sätt. Men är det egentligen så oförargligt? I sin beundransvärda bok från 1975, A Social History of Museum, återger Kenneth Hudson de erfarenheter som en 1700-tals bokhandlare vid namn Hutton gjorde vid sitt besök i British Museum. Han frågade guiden - vilket uppfattades som en stor oförskämdhet - vad det var för föremål som de passerade i ilfart. Svaret löd:

What! would you have me tell you everything in the Museum? How is it possible? Besides, are not the names written upon many of them?

Hudson är en av de alltför få som kunnat behandla förhållandet makt - museum på ett vitalt sätt. Naturligtvis har det ändå skrivits åtskilligt om denna relation. Men eftersom museologin i första hand är ett humanistiskt ämne och perspektivet kulturanalytiskt har samhällsvetenskapliga förståelsemodeller tillämpats i begränsad omfattning.

Med sitt arbete från 1982, Makt och motmakt, fick rättssociologen Thomas Mathiesen en stor läsekrets långt utanför det egna ämnets gränser. Vad som stimulerar och engagerar är Mathiesens sätt att tänka. Motmakt mot makten har ju sällan gjorts till tema av samhällsforskare. Deras tema kan i hög grad sägas vara makt och vanmakt. Mathiesen vill inplantera den betydligt mer optimistiska motmakten i den politiska och samhällsvetenskapliga vokabulären, legitimera den och bidra till att utveckla dess former. Ty en del av vanmakten består nämligen just däri att motmakten inte erkänns som en möjlighet.

I en större studie om Museet som arbetsform avser jag att utifrån egna erfarenheter pröva de handlingsformer som Mathiesen anger. Och framförallt utifrån de omfattande egna erfarenheter som bygger på att museet kan vara, inte makten, men väl motmakten.

\section{MOTMAKTENS HANDLINGSFORMER}

Sina sex handlingsformer har Mathiesen gett beteckningarna arenautbrytning, informationsuridning, maktbildning, sakprioritering, premissformulering och som en samlande form - alternativutformning.

Arenautbrytning kommer inifrån det etablerade systemet. Poängen är, att medan man opererar på den etablerade arenan bryter en eller flera representanter inifrån klart mot åtminstone några av systemets premisser, så att det väcker uppmärksamhet inom en bredare offentlighet runt systemet. Kort sagt, man blir kvar där inne samtidigt som man bryter sig ut - och kan därför inte definieras som fullständigt oansvarig och rabulistisk.

Med informationsvridning avses, att så länge informationer om systemets sätt att hantera kortsiktiga krav förblir inne i systemet, har man $\mathrm{i}$ allt väsentligt kontroll över informationens effekter på andra. Spridningen av informationerna utanför systemet innebär att denna kontroll upplöses.

Poängen med maktbildning är: Man arbetar för att utveckla förändringar inom det etablerade systemet - reformer - som både representerar kortsiktiga krav från de underordnade i systemet och som, vid genomförandet, ger de underordnade en stärkt maktposition i arbetet för målsättningar på längre sikt.

Med sakprioritering avses att man priori- 
terar vissa saker eller sakområden, som anses särskilt viktiga, arbetar för och med dessa, och går om nödvändigt in i en klar konflikt med etablerade krafter. Alla andra saker eller sakområden låter man däremot ligga.

Med premissformulering menas konsten att klart formulera kritiska synpunkter på grundval av egna särskilt grundligt genomarbetade premisser, som därmed fungerar som alternativ till det etablerade systemets premisser. Man accepterar således inte att hamna $\mathrm{i}$ situationen att antingen låta sig indefinieras, som balanserad i centrum, eller utdefinieras som sektpräglad extremist. När Mathiesen använder begreppet alternativutformning är det inte formulerandet av alternativ till redan etablerade ordningar som han menar att det etablerade systemet skall genomföra. I stället är det fråga om bildandet av en alternativ offentlighet. $\mathrm{D} \vee \mathrm{s}$ bildandet av en egen arena för presentation av åsikter, debatt och kritik, som blir en sådan tyngdpunkt att andra dras dit för att debattera och för att undvika att bli kritiserade för att inte vilja debattera.

Naturligtvis är inte dessa handlingsformer omedelbart användbara i den museigrammatik som för övrigt ännu inte är skriven. Men i min planerade studie avser jag att pröva hypotesen huruvida inte etablerandet 1991 av Arbetets museum i Norrköping lyckades så förhållandevis bra just genom att etablera: En alternativ offentlighet.

Till det mest inspirerande som skrivits om museet som idé och praktik, i varje fall på svenska, hör Per Wästbergs uppsats Det sällsamma vardagsrummet. På ett ställe frågar han:
Vad ska samlas in och vad ska ställas ut? Ingen kan här veta något bestämt. Man făr känna sig fram med en intuition som bör vara skärpt och systematisk men som ändå tvingas arbeta efter olika linjer för varje ny generation. På det viset går debatten vidare: diskussionen om museerna är kulturdebatt $\mathrm{i}$ vidaste mening.

Men vem diskuterar idag museerna i kulturdebatten? Borde inte svaret vara uppenbart: givetvis museimännen själva med sina utställningar som debattbränsle. Men det svaret räcker inte. Det är just genom att kunna bruka många media museets särskilda egenart och stora styrka ligger. Det mångkulturella samhället kräver den mångkunnige museimannen. Och visst kan inte sällan intuitionen både vara skärpt och systematisk. Det oroväckande i sakernas tillstånd är istället att varje ny museigeneration synes $\mathrm{i}$ alltför hög grad efterlikna den gamla. Man värdesätter kontinuiteten alltför högt för att vilja bryta mot det museala ceremonielet. Sociologer är sällan upprorsmän, skriver Thomas Mathiesen. Och vill jag tillägga, än mer sällan museimänniskor. Utan att för den skull hårdra begreppen alltför långt skulle jag i sammanhanget gärna vilja tala om både befrielsemuseologi och aktivitetsmuseologi för att nu anknyta till kyrkans och skolans världar.

Kan det sägas tydligare? Öppna museerna! Ut med museimännen på gator och torg! In med publiken! Men för att denna operation skall lyckas och inte medföra både museimännens och publikens snara bortgång krävs en eftertänksam och förutseende metodik och pedagogik. 
ERIK HOFRÉN

OM BEHOVET AV MUSEOLOGISK FORSKNING

Avslutningsvis vill jag därför beröra det stora behovet av museologisk forskning och därvid dra några paralleller med ett annat område som intresserar mig särskilt, nämligen kooperationsforskningen.

Svenska museiförbundet konstaterar i ett aktuellt policydokument att behovet av idéutveckling, debatt och erfarenhetsutbyte kring museiverksamheten är stort, att bristen på forskning kring mål och metoder är påfallande och att det finns för få naturliga kontaktytor mellan forskning och praktisk verksamhet. SMF drar därav den naturliga slutsatsen att museivetenskapen nu måste etableras som ett eget universitetsämne med professurer, forskarutbildning och fasta forskningsresurser. Detta är oförbehållsamt bra. Mer reserverad förhåller jag mig till SMFs snäva definition av museivetenskap som kunskapen om sambällets bevarande och formedlande av kulturarv.

Kooperativa institutet publicerade 1992 en rapport om svensk kooperationsforsknings form och framtid, skriven av Jerker Nilsson, professor i kooperativ företagsekonomi. Forskningsområdet som sådant finner sina forskningsobjekt i skilda kooperativa företagsformer, ideologi, organisation, ekonomi. Det finns en nära växelverkan mellan forskning och praktisk verksamhet, just vad SMF efterlyser för den museologiska forskningen. Vad som också är av vikt i sammanhanget är att man under 1980-talet, skriver Nilsson, livligt har diskuterat hur den framväxande kooperationsforskningen skulle organiseras:

Framför allt har två modeller övervägts, nämligen en "matrismodell" respektive en "centrummodell". Matrismodellen har karaktär av "låt hundra blommor blomma", dvs dess filosofi är att forskningen ska ske på många ställen i landet utan någon samlad koordinering. Centrumtanken går ut på en kraftsamling inom en eller några få forskningsmiljöer.

Av dessa båda modeller förordas centrumtanken. I förhållande till den museologiska forskningen är kooperationsforskningen omfattande. Varför min slutsats är mycket enkel. För att en kvalificerad museologisk forskning skall komma till stånd i Sverige, och göra det så snart som möjligt, måste en kraftsamling ske. Låt mig sammanfatta;

- Behovet av en allsidig forskning rörande museerna är idag mycket stort och under de närmaste åren kommer detta att växa markant.

- Det är nödvändigt att bestämda, tämligen stora delar av den museologiska forskningen finansieras med offentliga medel på samma sätt som annan humanistisk och samhällsvetenskaplig forskning.

- Samtidigt finns det åtskilliga forskningsuppgifter som museologerna skulle kunna utföra för museiorganisationerna finansierade av dessa.

- En del av de kunskapsutvecklingsbehov som finns hos museiorganisationerna kan dessa inte själva tillmötesgå, här kan en samverkan ske.

- Den museologiska forskningen bör organiseras enligt centrummodell, dvs den museologiska forskningen bör koncentreras till några få universitet. Umeå universitet i första hand. 


\section{SUMMARY}

\section{The Green Porcelain Palace}

"The green porcelain palace" is described in H G Wells' well-known novel The Time Machine (1895). The author has chosen as his starting-point H G Wells' ideas about the global communication of knowledge and ideas as the remedy for all disputes, antagonisms and enmities afflicting our planet and menacing the continued existence of mankind. Looking at the museum and its role in cultural communication, which to a great degree is a question of offering historical knowledge and insights, the need to base this work on an analysis of an ever changing media-situation is stressed. H G Wells uses "the green porcelain palace" as a metaphor for an archive, which was founded when the construction of a Western culture began. Could it also be applied to the museum and its function in society?

What is the attitude of those working in a museum to the communicative task? Power over the media is a key-question; in a world falling apart ideologically it is important to make available to the citizens as many alternative ways of seeing and thinking as possible. Alternatives to reigning dogmas are to be found in the study of history. The author argues that power has to be met with counterpower to make possible a dynamic democratic development. He bases his belief on his experience as a director of the "Museum of Work" in Norrköping and suggests that the six ways to act in order to establish alternatives outlined by the Norwegian sociologist Thomas Mathiesen could also be used in museum communication. The study of such actions should be an important museological theme.
Göranzon, Bo: Kan informationssambället bli en ny upplysningstid? 1989 utgiven av Sveriges kristna socialdemokraters förbund. 1985.

Hofrén, Erik: Öppna museer!, i Museiperspektiv. 1986.

Hofrén, Erik: Mellan makt och Minne. Tvärsnitt 12. 1991.

Hofrén, Kerstin. Den varvade demokratin. Otryckt uppsats. Högskolan Falun/Borlänge. 1987.

Hudson, Kenneth: A Social History of Museums. London 1975.

Lumley, Robert, (red).: The Museum Time Machine. 1992.

Mathiesen, Thomas: Makt och motmakt. 1982.

Nilsson, Jerker: Svensk kooperationsforsknings form och framtid. Kooperativa institutet. 1992.

Sorenson, C.: Theme Parks och Time Machines; i The New Museology. (red.) Peter Vergo. 1991. Wells, H. G.: Tidmaskinen. 1986

Wells, H. G.: Kommande dagar. Lund 1987.

Erik Hofrén är direktör for Arbetets museum $i$ Norrköping. Han var 1967-1983 landsantikvarie i Kopparbergs län och cheffor Dalarnas museum. 1982-86 var han ordf $i$ Nämnden for konst, museer och utställningar samt ledamot av Statens kulturråd. Han var en av forfattarna till "70-talets museum" (1970) och har skrivit många betydelsefulla artiklar i kulturpolitiska och museologiska frågor. Adr: Arbetets museum, Laxholmen, S-602 21 Norrköping. Fax +46-(0)11-182290.

\section{LITTERATUR}

Alexander, Edward P.: Museums in Motion. 1980.

Braathen, Stein: Dialogens villkor och

Datasamfundet. 1983.

Fuentes, Carlos: In i 80-talet. Horisont 1980: 6. 